\title{
Adoption of Advanced Technologies are the Driving Force in Re-Shaping the Technology Based Startup Eco System
}

\author{
Syed Zakir Hussain, N.H.Mullick
}

\begin{abstract}
The main purpose of this study is to explore the role of advanced technologies in re-shaping the startup ecosystem, after all the startups are bringing in the second wave of tech entrepreneurship, which is normally called as "Digital Entrepreneurship". In the initial years, it was commonly observed that the founders of small enterprises replicate successful American business models and adapt them to the Indian environment. Today, companies are looking at the bigger picture. A whole new breed of startups is emerging which is prepared to solve India's problems through the integration of advanced technologies and innovations. Technology, backed by the internet, is on a path to transform not just our businesses, but also our lives. This study is going to explore various aspects of the technology based startup ecosystem and the enablers. The paper also discusses measures taken by governmental agencies like NITI Aayog to support the promotion of new-age technologies and their integration with the startup ecosystem. The literature, propositions and discussions also intended to provide a bridge between cutting-edge technologies and startup ecosystem. This study also suggests that success cannot be achieved without adopting new and advanced technologies which are the key pillars supporting this evolution. Innovation is the key catalyst for growth and technologies in providing business solutions as technology is evolving at a rapid pace. Continuous innovation is the key factor for any business as "Innovate or Die"' is becoming the new buzzword Globally.

Keywords: Entrepreneurship, Job Creation, Advanced Technology, High-Tech, Startup, Technological Disruption.
\end{abstract}

\section{INTRODUCTION}

Motivation from the story of successful startup , colossal market openings, improvement of cutting edge technologies and innovations, an empowering emotionally supportive network from government have been the key drivers for the tech-based Indian startup ecosystem. The Gujarat government, which has been on a continuous quest to encourage innovations that can help solve India's pressing problems, has launched the mega "Vibrant Gujarat Global Summit (VGGS)"in January 2019. Indian Prime Minister Narender Modi inaugurated the 9th edition of the Vibrant Gujarat Summit in Gandhi Nagar in the presence of thousands of delegates and business leaders from across the world. "India is now ready for business as never before. In the last 4 years, we have jumped 65 places in the Global Ranking

Revised Manuscript Received on October 22, 2019

Mr. Syed Zakir Hussain, Ph.D. Scholar, Ph.D. Schola, Centre for Management Studies, Jamia Millia Islamia University, New Delhi-110025.

Dr. N.H.Mullick, Professor, Center for Management Studies, Jamia Millia Islamia University, New Delhi-110025. of World Bank's Doing Business report but we are still not satisfied. I have asked my team to work harder so that India must be in the top 50 next year," he said in his inauguration speech. In this regard, NITI Aayog CEO Amitabh Kant has once again extended his support to the startups working in advanced technological domains such as Artificial Intelligence (AI), Cloud Computing, Blockchain, Robotic Process Automation (RPA), Virtual Reality/ Augmented Reality (VR/AR), Internet of Things (IoTs), Big Data and Data Analytics, etc. The emerging domains are Additive Manufacturing, Cyber Security, Edge/fog Computing, Sensors, 3D Modeling, etc and more and more startups are adopting all these cutting-edge technologies to solve social and economic issues of our time.

The worldwide Information Technology segment is being driven by a few patterns that mirror the quick advancement being made by the digital wave over the world. These high effect innovations are disturbing the current condition and making high effect on organizations, governments and citizens. However, this isn't the first time Amitabh Kant has come out supporting the growth and innovation of these technologies. During the 12th India Digital Summit, Amitabh Kant had said, "This is a period of huge technology disruption in India. Artificial Intelligence alone will generate the opportunity to the tune of $\$ 32$ billion. Advanced Robotics are already handling $25 \%$ of the jobs. This will rise to $45 \%$ in the coming years."

The improvement of cutting- edge technologies and their applications are significant donors and driving specialists to the tech-based startup ecosystem. These new and youthful cutting edge new businesses have assumed a noteworthy job in making occupations over the most recent couple of years. Cutting edge new companies begin lean yet develop quickly in the underlying years, and their activity creation is robust to the point that it balances work misfortunes coming about because of disappointments of early stage startups. We can presume that putting resources into innovation in beginning times in Indian new businesses is less secure in light of extra factors, for example, a constrained pioneering history, less created neighborhood advertise, generally low help for protected innovation and research-upheld advancement, and so on.

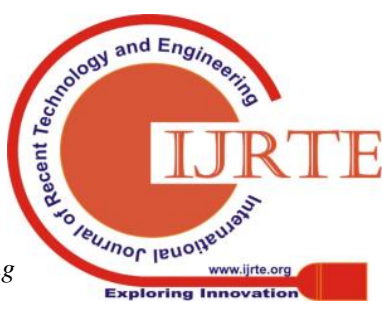


Innovation and technology startups are attempting to disturb each part of a consumer way of life. There is a huge change from our perspective and style of working-innovation has definitely changed the manner in which we work and how work is done, it has given a virtual stage to collaborate, arrange and trade without being physically present.

The idea of New Technology-Based Firms (NTBFs), presently prominently known as "Startups", isn't new. Open familiarity with NTBFs emerged in the mid-eighties, when a few conventional enterprises confronted serious issues and some quickly developing new ventures started to rise. NTBFs have, from that point, been viewed as a response to continuous auxiliary changes; they are viewed as a significant wellspring of new business and significant advertisers of mechanical change. The enormous corporate are assuming a significant job in the current mechanical situation to empower, advance and support tech-based new businesses in India. Ventures are typically contributing intensely to advance tech new companies as a result of specific reasons and advantages.

\section{Area of Technology Focus and Startups}

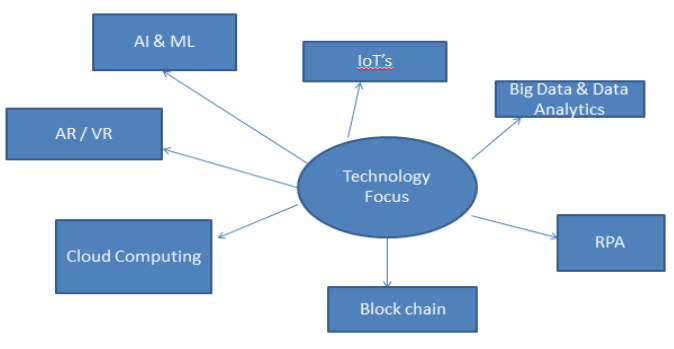

Figure 1.area of Technology Focus and Startups

$\checkmark$ When utilized as an instrument for an application, Internet of Things (IoT) has turned out to be one of the most extensive benefactors of startup ecosystem today. As of now at the middle phase of enterprises like energy management, social insurance, healthcare, logistics, Fintech and Agritech, IoT, in combination with AI, can possibly disturb every one of these verticals. Recently managed by huge players like IBM, Google, Intel, Cisco, Ericsson, Apple and Amazon, the IoT space has now turned into a startup ecosystem empowering agent over the world. While it was the web that drove the development of e-commerce startups in the mid 2000s, IoT has been encouraging the development of this present decade's tech based new emerged startups.

$\checkmark$ It is evaluated that the IoT space will accumulate $\$ 6$ trillion worth of speculations somewhere in the range of 2015 and 2020. While the overall spending on IoT as of now remains at $\$ 674$ billion, the spending is required to reach $\$ 772.5$ billion out of 2018 , which is an expansion of $14.6 \%$. $\checkmark$ As indicated by Carrie MacGillivray, VP, IoT and Mobility at IDC, by 2021, over 55\% of spending on IoT tasks will be on programming and administrations. This is legitimately in accordance with the aftereffects of IDC's 2017 Global IoT Decision Maker Survey, where associations have demonstrated that product and administrations are the key territories of centered speculation for their IoT ventures.

$\checkmark$ IoT startups are presently driving the stage with monsters finishing them either speculations, subsidizing or acquisitions. As referenced, all inclusive, the space is set to witness $\$ 6$ trillion worth of speculations somewhere in the range of 2015 and 2020. Indian new businesses, as well, are being brooded worldwide with the assistance of worldwide players.

$\checkmark$ As indicated by Zinnov, in India, 120 IoT startups have gotten over \$169 million subsidizing since 2006 (till may 2017). Huge speculators that have made IoT-centered venture funders are Tiger Global Management, Blume Ventures and Qualcomm Ventures.

$\checkmark$ Honeywell Ventures and a Tokyo-based endeavor store Trend Micro have propelled speculation assets with a corpus of $\$ 100$ million each, to put resources into IoT-based new companies. Blume Ventures, a standout amongst the most dynamic VCs in India, has as of late reported designs to dispatch a \$100-million Investment Fund III that will likewise have an emphasis on IoT new businesses.

Technology and Innovation-driven startups are attempting to upset each part of a consumer way of life. There is a noteworthy change from our perspective and style of working, these new companies have changed our methodologies, innovation has radically changed the manner in which we work and work is performed, it has given a virtual stage to collaborate, arrange and trade things without being there physically present, in the event that we think about the conventional age and startup age, we will discover the distinctions as referenced beneath.

Table 1.Comparative approach between traditional and Startups age

\begin{tabular}{|l|l|l|l|}
\hline Traditional Approach & $\begin{array}{l}\text { Startup Age } \\
\text { Approach }\end{array}$ & $\begin{array}{l}\text { Supported } \\
\text { Startup }\end{array}$ & Technology Used \\
\hline $\begin{array}{l}\text { Before moving to any } \\
\text { new location we use to } \\
\text { store unnecessary items } \\
\text { in warehouse }\end{array}$ & $\begin{array}{l}\text { But now we goes } \\
\text { for on-demand } \\
\text { storage for storing } \\
\text { unnecessary items. }\end{array}$ & BoxMySpac & Online Apps \\
\hline
\end{tabular}


International Journal of Recent Technology and Engineering (IJRTE) ISSN: 2277-3878, Volume-8 Issue-3S2, October 2019

\begin{tabular}{|c|c|c|c|}
\hline $\begin{array}{l}\text { At airport or at railway } \\
\text { station we use to stand } \\
\text { in a long queue to book } \\
\text { a cab from pre-paid taxi } \\
\text { booth. }\end{array}$ & $\begin{array}{l}\text { Now we use mobile } \\
\text { apps to book cabs } \\
\text { online to reach any } \\
\text { location without } \\
\text { any hassle. }\end{array}$ & OLA, UBER & Ruckus Smart wi-fi network \\
\hline $\begin{array}{l}\text { Hotel searching was a } \\
\text { difficult task, we have to } \\
\text { face lot of challenges to } \\
\text { handle agents. }\end{array}$ & $\begin{array}{l}\text { Now book an } \\
\text { affordable hotel } \\
\text { online. }\end{array}$ & OYO & $\begin{array}{l}\text { Program: JavaScript, HTML5, } \\
\text { CSS } \\
\text { Web Host: GoDady, Amazon } \\
\text { Traffic Analysis Tools: } \\
\text { Google Analytic, Mouse Flow } \\
\text { \& New Relic }\end{array}$ \\
\hline $\begin{array}{l}\text { For any transaction we } \\
\text { must carry cash, even } \\
\text { mobile recharge was a } \\
\text { big task, we must go to } \\
\text { any shops to recharge or } \\
\text { top-ups }\end{array}$ & $\begin{array}{l}\text { Make online } \\
\text { payment using } \\
\text { many applications. }\end{array}$ & Paytm & $\begin{array}{l}\text { JavaScript, HTML5, UTF8, } \\
\text { PNG, } \\
\text { DigiCert }\end{array}$ \\
\hline $\begin{array}{l}\text { Dealing with Property } \\
\text { agents to buy or rent a } \\
\text { house. }\end{array}$ & $\begin{array}{l}\text { Search for house or } \\
\text { any property and } \\
\text { directly contacts } \\
\text { with owner }\end{array}$ & Housing.com & $\begin{array}{l}\text { Google Analytics Tools, Boob } \\
\text { Range for gmail, Drop Box, G } \\
\text { Suit, MSOfiice } 365\end{array}$ \\
\hline $\begin{array}{l}\text { After getting a house on } \\
\text { rent, arranging a } \\
\text { furniture was a } \\
\text { challenge, we use to } \\
\text { visit furniture market. }\end{array}$ & $\begin{array}{l}\text { Now order furniture } \\
\text { online }\end{array}$ & Pepper fry & $\begin{array}{l}\text { Online Apps build on PHP, } \\
\text { Open ERP, Google Analytics }\end{array}$ \\
\hline $\begin{array}{l}\text { Dealing with local } \\
\text { vegetable vendors was } \\
\text { challenge due to } \\
\text { language problem }\end{array}$ & $\begin{array}{l}\text { Purchase groceries } \\
\text { using mobile apps. }\end{array}$ & $\begin{array}{l}\text { Grofers, Big } \\
\text { Basket }\end{array}$ & $\begin{array}{l}\text { User Interface is built on: } \\
\text { Angular Js, Scala, Radis, } \\
\text { Nodel. Js , Python }\end{array}$ \\
\hline $\begin{array}{l}\text { Being a health } \\
\text { enthusiast , finding a } \\
\text { gym was difficult }\end{array}$ & $\begin{array}{l}\text { Now use mobile } \\
\text { apps to find near by } \\
\text { gym. }\end{array}$ & Gympik & Health care and fitness Apps \\
\hline $\begin{array}{l}\text { Finding an auto } \\
\text { rickshaw to goto tuition } \\
\text { and other location was a } \\
\text { challenge for family } \\
\text { member. }\end{array}$ & $\begin{array}{l}\text { Now we can use } \\
\text { mobile apps. to } \\
\text { book an auto and } \\
\text { get online help for } \\
\text { test preparation. }\end{array}$ & Toppr & $\begin{array}{l}\text { Web application used and } \\
\text { developed in Python which } \\
\text { follow the } \\
\text { Model-view-controller(MVC) } \\
\text { architecture }\end{array}$ \\
\hline $\begin{array}{l}\text { Finding a south Indian } \\
\text { cloth in Delhi was a } \\
\text { challenge }\end{array}$ & $\begin{array}{l}\text { Use mobile apps. } \\
\text { To select and buy a } \\
\text { sari from huge } \\
\text { range of collection } \\
\text { online }\end{array}$ & Myntra & $\begin{array}{l}\text { Akamai-Fast DNS intelligent } \\
\text { platform, Comodo } \\
\text { SSL,HTML5, PHP }\end{array}$ \\
\hline $\begin{array}{l}\text { Finding a Plumber and } \\
\text { Electrician for } \\
\text { household small issues } \\
\text { was again a big } \\
\text { challenge in new place. }\end{array}$ & $\begin{array}{l}\text { Use application to } \\
\text { find plumber and } \\
\text { electrician in your } \\
\text { area. }\end{array}$ & Urban Clap & $\begin{array}{l}\text { Using three Platform, } \\
\text { Android, IOS \& web, back } \\
\text { end is written in Node.Js with } \\
\text { Redis cacthing layer platform. }\end{array}$ \\
\hline
\end{tabular}

\begin{tabular}{|c|c|c|c|}
\hline & $\begin{array}{l}\text { Bhalla \& Vishal } \\
\text { Bansal in } 2013\end{array}$ & Learning ) & commercial consumers. \\
\hline $\begin{array}{l}\text { Ecolibrium } \\
\text { Energy }\end{array}$ & $\begin{array}{l}\text { Chintan Soni \& } \\
\text { Harit Soni in } \\
2011 \text { in } \\
\text { Ahmedabad }\end{array}$ & $\begin{array}{l}\text { loT(Big } \\
\text { Data) }\end{array}$ & $\begin{array}{l}\text { Provides energy } \\
\text { intelligence to commercial } \\
\text { and Industrial consumers }\end{array}$ \\
\hline Smarton & $\begin{array}{l}\text { Mahesh } \\
\text { Lingareddy, } \\
\text { Nasri Reddy \& } \\
\text { Rohit Rathi in } \\
2014\end{array}$ & IoT & $\begin{array}{l}\text { Provides an Intelligent } \\
\text { connected platform Tronx } \\
\text { offering highly customized } \\
\text { care through next } \\
\text { generation smart devices } \\
\text { across loT vertical }\end{array}$ \\
\hline $\begin{array}{l}\text { Armis } \\
\text { Security }\end{array}$ & $\begin{array}{l}\text { Nadir Izrael in } \\
2015\end{array}$ & IoT & $\begin{array}{l}\text { Provide visibility into all IoT } \\
\text { enabled devices that are } \\
\text { unmanaged across IT }\end{array}$ \\
\hline
\end{tabular}

Below are some major startups based on AI Technology

Table 3.Top five illustrative AI based startups

\begin{tabular}{|c|c|c|c|}
\hline $\begin{array}{l}\text { Startup } \\
\text { Name }\end{array}$ & Founder Details & Technology & Purpose \\
\hline $\begin{array}{l}\text { 1) Absentia } \\
V R\end{array}$ & $\begin{array}{l}\text { 2) Three BITS } \\
\text { Pilani Goa drop } \\
\text { out engineers } \\
\text { Shubham } \\
\text { Mishra, } \\
\text { Harikrishna } \\
\text { Valiyath \& } \\
\text { Vrushali } \\
\text { Prasade in } 2015\end{array}$ & $\begin{array}{l}\text { 3) Al with } \\
\text { Deep } \\
\text { Learning } \\
\text { technology }\end{array}$ & $\begin{array}{l}\text { 4) Aims to } \\
\text { bridge the } \\
\text { gap } \\
\text { between } \\
\text { existing } \\
\text { e-content } \\
\text { and VR and } \\
\text { extend their } \\
\text { experience } \\
\text { to } \\
\text { empowered } \\
\text { game users. }\end{array}$ \\
\hline 5) NiKi.ai & $\begin{array}{l}\text { 6) Founded by } \\
\text { IIT Kharagpur } \\
\text { Alumni Sachin } \\
\text { Jaiswal, Nitin } \\
\text { Babel \& Shishir } \\
\text { Modi in } \\
\text { Bengaluru }\end{array}$ & $\begin{array}{l}\text { 7) Al-natura } \\
\text { I language } \\
\text { processing }\end{array}$ & $\begin{array}{l}\text { 8) It's an AI } \\
\text { powered } \\
\text { shopping } \\
\text { assistant } \\
\text { using } \\
\text { chatbot SDK }\end{array}$ \\
\hline
\end{tabular}


Adoption of Advanced Technologies are the Driving Force in Re-Shaping the Technology Based Startup Eco System

\begin{tabular}{|c|c|c|c|}
\hline 9) Flutura & $\begin{array}{l}\text { 10) Srikanth } \\
\text { Murlidhara \& } \\
\text { Derick Jose in } \\
\text { Bengaluru in } \\
\text { the year of } \\
2012\end{array}$ & $\begin{array}{l}\text { 11) Al- Big } \\
\text { data } \\
\text { analytics }\end{array}$ & $\begin{array}{l}\text { 12) Flutura } \\
\text { is a big data } \\
\text { analytics } \\
\text { solution } \\
\text { provider } \\
\text { with a vison } \\
\text { to transform } \\
\text { operational } \\
\text { outcome by } \\
\text { monetizing } \\
\text { machine } \\
\text { data. }\end{array}$ \\
\hline $\begin{array}{l}\text { 13) Uncann } \\
\text { y Vision }\end{array}$ & $\begin{array}{l}\text { 14) Ranjit } \\
\text { Parakkal in } \\
\text { Bengaluru }\end{array}$ & $\begin{array}{l}\text { 15) Al with } \\
\text { Deep } \\
\text { learning }\end{array}$ & $\begin{array}{l}\text { 16) It } \\
\text { provides } \\
\text { cost } \\
\text { effective } \\
\text { and scalable } \\
\text { security } \\
\text { solution for } \\
\text { next } \\
\text { generation } \\
\text { safe cities } \\
\text { and smart } \\
\text { industries } \\
\text { like banks. }\end{array}$ \\
\hline $\begin{array}{l}\text { 17) Innefu } \\
\text { Labs }\end{array}$ & $\begin{array}{l}\text { 18) Tarun Wig } \\
\text { and Abhishek } \\
\text { Sharma in } 2012\end{array}$ & 19) $\mathrm{Al}$ & 20) \\
\hline
\end{tabular}

Below are some major startups based on Blockchain

Table 4.Top five illustrative BlockChain Technology based startups

\begin{tabular}{|c|c|c|c|}
\hline $\begin{array}{l}\text { Startup } \\
\text { Name }\end{array}$ & Founder Details & Technology & Purpose \\
\hline $\begin{array}{l}\text { Primechain } \\
\text { Technologies }\end{array}$ & $\begin{array}{l}\text { Rohas Nagpal \& } \\
\text { Shinam Arora in } \\
2016 \text { in Pune }\end{array}$ & BlockChain & $\begin{array}{l}\text { This startup is a key to } \\
\text { developing blockchain } \\
\text { based solution for the } \\
\text { Banking system in India }\end{array}$ \\
\hline $\begin{array}{l}\text { Elemential } \\
\text { Labs }\end{array}$ & $\begin{array}{l}\text { Raunaq } \\
\text { Vaisoha, Anil } \\
\text { Dukkipatty, } \\
\text { Sahil Kathpal \& } \\
\text { Aaryaman Vir } \\
\text { Shah }\end{array}$ & BlockChain & $\begin{array}{l}\text { It's Products are sector } \\
\text { agnostic and are used } \\
\text { to create KYC utility by } \\
\text { NSE }\end{array}$ \\
\hline $\begin{array}{l}\text { Sofocle } \\
\text { Technologies }\end{array}$ & $\begin{array}{l}\text { Nidhi Chamria } \\
\text { in } 2016 \text { in }\end{array}$ & BlockChain & $\begin{array}{l}\text { It develops blockChain } \\
\text { powered enterprise }\end{array}$ \\
\hline
\end{tabular}

\begin{tabular}{|l|l|l|l|}
\hline & Hyderabad & & $\begin{array}{l}\text { solution for smart } \\
\text { contract, supply chain } \\
\text {,finance,helth care, } \\
\text { insurance etc. }\end{array}$ \\
\hline $\begin{array}{l}\text { Cateina } \\
\text { Technologies }\end{array}$ & $\begin{array}{l}\text { Sanachit Mehra } \\
\text { in } 2017\end{array}$ & BlockChain & $\begin{array}{l}\text { It provides BlockChain } \\
\text { solution for business } \\
\text { process automation. }\end{array}$ \\
\hline EzyRemit & $\begin{array}{l}\text { Vishal Kanvaty } \\
\text { a Abhijit }\end{array}$ & BlockChain & $\begin{array}{l}\text { This solution is focused } \\
\text { on blockChain and } \\
\text { cryptocurrency } \\
\text { technology for trust }\end{array}$ \\
& & & $\begin{array}{l}\text { validation, distribted } \\
\text { computing and } \\
\text { simplification of } \\
\text { process. }\end{array}$ \\
\hline
\end{tabular}

Below are some major Startups based on Cloud Computing

Table 5.Top Five illustrative Cloud Computing based startups

\begin{tabular}{|c|c|c|c|}
\hline Startup Name & Founder Details & Technology & Purpose \\
\hline ITILITE & $\begin{array}{l}\text { Mayank Kukreja in } \\
2017\end{array}$ & $\begin{array}{l}\text { Cloud } \\
\text { Computing }\end{array}$ & $\begin{array}{l}\text { It Aims to use Cloud } \\
\text { Computing } \\
\text { technology to bring } \\
\text { convenience, } \\
\text { efficiency and } \\
\text { Innovation to } \\
\text { Corporate travel }\end{array}$ \\
\hline INCREFF & $\begin{array}{l}\text { Romil Jain \& Rajul } \\
\text { Jain in } 2016\end{array}$ & $\begin{array}{l}\text { Cloud } \\
\text { Computing }\end{array}$ & $\begin{array}{l}\text { This startup is } \\
\text { mainly focused on } \\
\text { fashion and } \\
\text { Lifestyle brands and } \\
\text { deliver significant } \\
\text { solution for sales } \\
\text { and Inventory } \\
\text { management. }\end{array}$ \\
\hline XOXODAY & $\begin{array}{l}\text { Sumit } \\
\text { Khandelwal,Manoj } \\
\text { Agarwal,Abhishek } \\
\text { Kumar \& Kaushal } \\
\text { Agarwal in } 2012\end{array}$ & $\begin{array}{l}\text { Cloud } \\
\text { Computing }\end{array}$ & $\begin{array}{l}\text { It provides HR } \\
\text { related solution } \\
\text { focused on } \\
\text { experimental } \\
\text { employee } \\
\text { engagement, } \\
\text { rewards \& Loyalty } \\
\text { program and } \\
\text { manage employee } \\
\text { productivity. }\end{array}$ \\
\hline
\end{tabular}




\begin{tabular}{|c|c|c|c|}
\hline SQUADCAST & $\begin{array}{l}\text { Amiya Adwitya in } \\
2017\end{array}$ & $\begin{array}{l}\text { Cloud } \\
\text { Computing }\end{array}$ & $\begin{array}{l}\text { It's an incident } \\
\text { management } \\
\text { platform focused on } \\
\text { helping tech team } \\
\text { accelerate } \\
\text { innovation and } \\
\text { iterate faster. }\end{array}$ \\
\hline VdoCipher & $\begin{array}{l}\text { Sidhant Jain \& } \\
\text { Vibhav Sinha in } \\
2014\end{array}$ & $\begin{array}{l}\text { Cloud } \\
\text { Computing }\end{array}$ & $\begin{array}{l}\text { It's a secure video } \\
\text { streaming solution } \\
\text { for business looking } \\
\text { to provide } \\
\text { economical video } \\
\text { solution with } \\
\text { internet rich content. }\end{array}$ \\
\hline
\end{tabular}

\section{LITERATURE REVIEW}

Chang, C. C. (2012) clarified his view and clarified the reason for his investigation, the fundamental goal is to investigate the dynamic capacities expected of data. Utilizing a systematical methodology that joins Q-system and poll study, the author gathered 98 proclamations acquired from meeting ten IT business people. A sum of 44 out of 98 basic explanations were removed as Q-tests dependent on purposive examining. In this way, 20 specialists utilized Q-system as far as the example the 44 articulations to create a reconsidered survey to examine 500 Taiwan IT-based organizations. As per the reactions of the 281 substantial duplicates of survey got, advertise arranged affectability, the capacity to ingest learning, person to person communication capacity, and the integrative capacity to convey and arrange are the dynamic abilities expected of IT business visionaries. The outcomes can be utilized by IT business people of SMEs in the self-appraisal of capacities and the advancement of dynamic abilities during their startup and development stages. They can likewise be connected to sustaining successors and developing new business visionaries. This investigation explains the inborn powerful capacities of IT business people, and recognizes the required parts of such abilities and their needs. The outcomes can be utilized in administrative basic leadership and faculty preparing, the two of which help business people in structure upper hands.

Verkasalo, H. (2009) distinguished a few estimates that mirror the dissemination of the portable web. The estimations are executed with a recently created handset-based portable administration look into stage that gives a novel method to precisely recognize patterns occurring in versatile administration utilization. These measures are shown for a situation model contrasting Finnish early-adopter cell phone clients somewhere in the range of 2005 and 2006 (500 and 695 users).The consequences of the examination demonstrate that the versatile web has not yet developed on a huge scale in
Finland.The estimation system can be additionally used in both cross-sectional and longitudinal investigation settings in assessing the rise of the portable web. No other experimental research strategy gives the precision and extent of utilization estimations finished with the handset-based research stage. Be that as it may, the weaknesses of the new technique ought to be figured it out. Despite what might be expected, administrators have marginally expanded their capacity, conceivably in light of the fact that handset packaging with versatile memberships is currently permitted in Finland.The paper proposes that the portable web has not risen generally, even in early-adopter client fragments.

Swiercz, P. M., \& Lydon, S. R. (2002) clarified the fundamental factors behind the disappointment of any hot new companies. This investigation configuration to legitimately challenge the recommendation apparent in tried and true way of thinking, scholastic hypothesis and magnificent research holding that the organizer must be traded all together for the organization to proceed to develop and create. The fruitful pioneering pioneer is that who can anticipate how a given individual will fit in the following degree of organization development. He realizes when to advance, end and teach or contract from the outside of organization stock. The aftereffects of this examination make a commitment to three insightful fields of research notwithstanding giving handy exhortation to startup organizers and their consultants. The exploration goals were customized.

Scarmozzino, E., Corvello, V., \& Grimaldi, M. (2017) investigated the commitment of expert long range interpersonal communication sites (PSNWs) to enterprising learning in innovative new businesses. What's more, in the present paper, the connections between scholarly capital (IC) and PSNW-bolstered pioneering learning have been investigated.The paper depends on information gathered through a poll conveyed to business people and chiefs of innovative new businesses. So as to comprehend the conduct of startuppers in PSNWs two hypothetical develops have been concocted, which could put into proof information sharing and learning looking for events. In these develops, enterprising learning speaks to the reliant variable, while IC parts are considered as arbitrators. The got outcomes have been dissected through various leveled regression. Results have demonstrated that PSNWs bolster the learning procedures of start uppers and that the social capital, one of the parts of IC goes about as a significant arbiter in the theorized connections between information looking for exercises and pioneering learning. This study has taken an example of medium estimated enterprises into thought. Future research could be 
centered around bigger businesses, so as to approve the got outcomes. What's more, it could be fascinating to look at further factors influencing the improvement of innovative learning rehearses in start uppers and bigger associations.

Matzler, K., Friedrich von den Eichen, S., Anschober, M., \& Kohler, T. (2018) stated that the mission to disturb has moved toward becoming Silicon Valley's campaign and new companies over the world are shaking up existing businesses. Previous Cisco CEO John Chambers predicts that "40\% of organizations in this room, shockingly, won't exist in an important manner in 10 years", Cisco CEO John Chambers at the goliath Cisco client's gathering in 2015.Europe is falling behind. A McKinsey study asserts that lone $12 \%$ of the digitalization potential has been utilized to date, contrasted with $18 \%$ in the USA (Bughin et al., 2016). The first round of advanced change was won by Silicon Valley. New innovations are changing the whole monetary structure, society and the manner in which we live, work and expend with amazing rate. The advanced change is uncommon as far as speed, range and impact. This example of interruption is astoundingly steady. It describes most problematic changes in business history (Christensen, 1997) and still remains constant in the time of advanced change: Netflix killed Blockbuster, Amazon disturbed the retail business, and it was not the "Huge Four" music names that presented MP3 or gushing plans of action. The advanced change is reforming each industry, and the disruptors all the time are new contestants while officeholders face the trailblazer's problem. Their plans of action and their center skills make them great at supporting development yet ruin them in troublesome changes.

Sonderegger, P., \&Täube, F. (2010) clarified that the nearby perspective on bunches and accentuate the reciprocal job of non-neighborhood linkages, specifically diasporas, representing the model utilizing the instance of the development of the Bangalore IT group. The oddity of the paper lies in its longitudinal character. The creators are subsequently ready to recognize how the jobs of nearby and non-neighborhood systems contrast crosswise over life cycle stages; additionally, and find that diasporas can trigger or quicken neighborhood improvement. They talk about suggestions for chiefs and arrangement producers. The job of neighborhood bunches has been important to researchers and policymakers in universal business alike. Research found that groups empower a district to grow quicker contrasted with scattered monetary action, in view of on a nearby centralization of contending and participating firms and refined household request. Situating in a group has certain advantages for firms coming from pooling of human capital and supporting establishments changing by industry and global specialization. In this paper, the author grow the view on diasporas as they explore it through an all the more fine-grained approach, separating among immediate and aberrant impacts on group development. So as to do as such, we incorporate bunch life cycle (CLC) hypothesis and recognize the various jobs of the diaspora as per CLC stage. They unravel the snare of nearby and non-neighborhood associations and add to the continuous hypothetical exchange: the discoveries compare to prior examinations about the pertinence of diasporas and in part support Zaheer et al. (2009) and Nanda and Khanna (approaching) while at the same time including further research a more disaggregate level as to worldly and spatial measurements. They likewise draw suggestions for professionals; while administrators may wish to reevaluate area choices dependent on this disaggregate point of view and the job of diasporas and other non-nearby linkages, approach creators may need to consider over again their endeavors and motivations to pull in outside MNCs in local improvement activities.

\section{RESEARCH OBJECTIVE}

To understand the role of advanced technology in Indian Startup.

To explore the level of adoption of Advanced technology in startup verticals.

To evaluate the role of government and other agencies to promote the tech-based Indian startups.

\section{RESEARCH METHODOLOGY}

Our study is based on secondary data. The secondary data required for the studies were collected from various international journals, Published online books , Published Reports, Various Analyst Reports, Technical Journals, trade magazines, Databases such as Forrester, OVUM , Gartner, government and regulatory published material and their website, websites of various media companies like Inc42.com, IndianWeb2.com, NASSCOM, yourstory.com and various publications related to the topic under study.

\section{RESEACRH FINDINGS / ANALYSIS}

CERTAIN FACTS ABOUT NEW TECHNOLOGICAL DEVELOPMENT AND THEIR IMPACT ON STARTUP ECOSYSTEM

- In the course of the most recent decade, the Indian innovation and technology industry has changed India and is 
on track to accomplish its yearning of $\$ 225$ billion incomes by 2020 .

- Huge auxiliary movements are in progress in the worldwide client scene and the innovation business is at the cusp of an enunciation.

- Significant headroom for growth with global enterprise spends at $\$ 4$ trillion in 2025;

However, the nature of opportunity will be markedly different.

- Indian technology and services industry has the potential to achieve revenues of $\$ 350$ billion by 2025 at $10-11 \%$ CAGR over the next decade by capturing the digital opportunities.

- Domestic technology market will also grow rapidly to $\$ 70+$ billion in 2025 spurred by "Digital India".

- Success of startup ecosystem will require concerted effort between industry, academia and government (Triple Helix).

- Digital innovators disrupt existing models and have captured $20-25 \%$ incremental revenues in select sectors.

- Global technology and business services enterprise spend likely to touch $\$ 4$ trillion by $2025 ; 60 \%$ driven by digital technologies

- $80 \%$ of incremental spend to be around digital technologies, resulting in significant shift in mix.

- Indian technology and service industry revenues could reach $\$ 225$ billion by 2020, $\$ 350$ billion by 2025 .

- Decoupling of revenue and headcount likely to accelerate over the next 5 years.

- Domestic 2025 Indian opportunity may reach $\$ 70-90$ billion.

(Source: Gartner, NASSCOM team Analysis )

\section{ARTIFICIAL \\ INTELLIGENECE \\ STARTUPS \\ LANDSCAPE}

- Advanced Analytics, Natural Language Processing, Computer Vision, Robotic Process Automation and Speech Recognition are the key business categories of companies working in AI.

- While overall funding increased from \$44 million in 2016 to $\$ 73$ million in 2017 , new startups incorporated dropped from 146 to 81 implying Investor focus shift to more mature startups with increased investments.

- Advanced Analytics and Computer Vision techniques are the interest areas of more than $50 \%$ of firms that participated in the NASSCOM AI Game Changer Awards 2018.

- Companies like TCS, Infosys, Wipro, HCL, IBM, Capgemini are advancing in AI and have created AI-based platforms like Ignio, NIA, Holmes, etc. Similarly, large fund managers are continuously in the process of investing in AI ventures.

- Banking, Financial Services and Insurance (BFSI) dominate most of the AI innovations under AI Game Changer Awards attracting $26 \%$ of the firms followed by Retail, Healthcare and Manufacturing.

- Government of India has allocated \$477 million for emerging technologies and set up expert committees. Large companies also provide nurturing environments in the form of incubators by offering mentoring, technology platforms, funding, etc.

(Source: Gartner Market Databook 1Q18, Gartner Cloud Forecast 2018Q1, Deloitte Analysis)

\section{AI Business Categories:}

\begin{tabular}{|c|c|c|}
\hline $\begin{array}{l}\text { Advanced Analytics: } \\
\text { Advanced Analytics } \\
\text { majorly represent machine } \\
\text { learning algorithms which } \\
\text { work on large data sets to } \\
\text { make predictions and } \\
\text { recommendations like } \\
\text { predictive modeling etc. }\end{array}$ & $\begin{array}{l}\quad \text { Natural Language } \\
\quad \text { Processing(NLP) } \\
\text { NLP allows the engagement } \\
\text { of virtual a gents that will } \\
\text { interact with humans and } \\
\text { provide a solution }\end{array}$ & $\begin{array}{l}\quad \text { Computer Vision } \\
\text { Computer Vision allows } \\
\text { generation of intelligent } \\
\text { and insightful description of } \\
\text { the visual image by using } \\
\text { signals received like face } \\
\text { recognition, automated } \\
\text { medical image analysis, etc. }\end{array}$ \\
\hline
\end{tabular}

\begin{tabular}{|l|}
\multicolumn{1}{|c|}{ Robotics Process Automation } \\
RPA enables a robot or a software to \\
collect, interpret, extract knowledge \\
and information to make transactions \\
and communicate with other systems \\
like automated customer order \\
processing, etc.
\end{tabular}

Speech Recognition:
Speech recognition allows
computers to interpret human
speech and provide relevant
solutions. It converts spoken
words into text and navigational
commands.

Startups based on AI category Advanced Analytics:

$\checkmark$ Predictive Modeling Application

$\checkmark$ Demand Forecasting Application

$\checkmark$ Customer Segmentation Application

$\checkmark$ Cross Selling and Up Application

$\checkmark$ Selling Application

$\checkmark$ Dynamic Pricing Application

$\checkmark$ Risk Analysis Application

$\checkmark \quad$ Startups based on AI category Natural 
Language Processing (NLP):

$\checkmark$ Machine Translation

$\checkmark$ Paraphrasing

$\checkmark \quad$ Natural Language Generation

$\checkmark$ Image Captioning

$\checkmark \quad$ Topic Modeling

$\checkmark$ Speech Tagging

$\checkmark$ Startups based on AI category Computer Vision:

$\checkmark$ Face Detection

$\checkmark$ Object Recognition

$\checkmark$ Facial Recognition

$\checkmark$ Eye Tracking

$\checkmark$ Emotion Recognition

$\checkmark$ Motion Detection

$\checkmark$ Startups based on AI category Robotics Process Automation:

$\checkmark \quad$ Manipulating Data

$\checkmark \quad$ Trigger Responses

$\checkmark$ Communicating with Digital Systems

$\checkmark$ Creating virtual workforce

$\checkmark$ Startups based on AI category Speech Recognition:

$\checkmark$ Speaker Identification

$\checkmark$ Language Identification

$\checkmark \quad$ Speech to text processing

$\checkmark$ Multimodal Interaction

$\checkmark$ Voice Web Search

$\checkmark \quad 400+$ AI startups and $\sim \$ 150$ million invested in the last 5 years.

$\checkmark \quad$ Investor focus shift to more mature startups with increased investments but fewer new startups being incorporated.

Top 5 Artificial Intelligence Startups Investors

\begin{tabular}{|l|l|l|}
\hline Company & $\begin{array}{l}\text { Investment } \\
\text { in USD }\end{array}$ & Investors \\
\hline SigTuple & 19 & $\begin{array}{l}\text { Accel Partners; IDG Ventures } \\
\text { India; Endiya } \\
\text { Partners; Pi Ventures; Axilor } \\
\text { Ventures }\end{array}$ \\
\hline $\begin{array}{l}\text { Active } \\
\text { Intelligence }\end{array}$ & 8 & $\begin{array}{l}\text { Vertex Ventures; Dream } \\
\text { Incubator; Kalaari } \\
\text { Capital; CreditEase; IDG } \\
\text { Ventures India }\end{array}$ \\
\hline Observe & 8 & Undisclosed \\
\hline Uniphore & 7 & India Infoline; IDG Ventures \\
\hline $\begin{array}{l}\text { CreditVidya } \\
5\end{array}$ & 5 & Matrix Partners; Kalaari Capital \\
\hline
\end{tabular}

Other Key Investors in Artificial Intelligence Startups

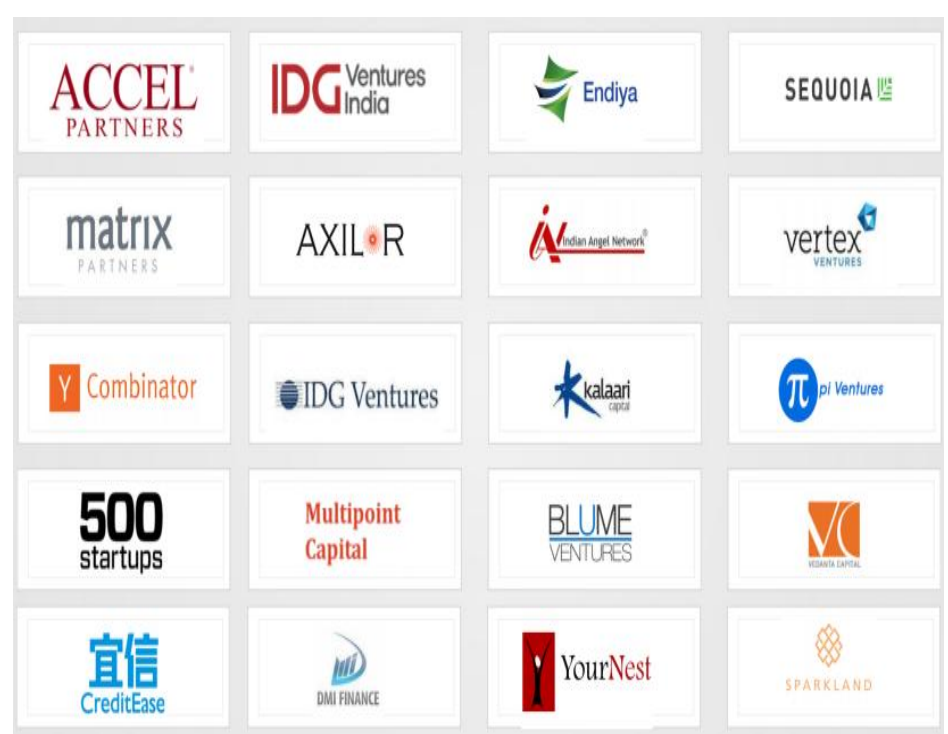

Source: Tracxn Data and NASSCOM

Future AI Application on which more startups are working:

o Home and Service Robots: Specific robots for household work like package delivery, cleaning, security etc.

o Artificial Intelligence Doctor: Knowing individual vulnerabilities to particular diseases and call for help even if the human faints.

o AI based News and Stories: News and stories are expected to be written by software robots and tailored according to personal preferences..

o Search: Search to become dialog based rather than client server interaction.

o Autonomous Trains and Planes: Trains and planes carrying cargo will get autonomous.

o Robotic Food Delivery: Food to be raised by robotic vehicles. Source: Stanford, Nulltx, NASSCOM

Emergence of Cloud Computing and Startups

- Cloud computing has risen as the next wave in figuring out the business and has been progressively adopted over organizations and by the consumers. While Software-as-a-Service contributions have dependably been prevailing, Infrastructure-as-a-Service and Platform-as-a-Service are picking up steam with the ascent of utilization cases crosswise over modern advances, for example, Artificial Intelligence, Machine Learning, Advanced Analytics, Immersive Media, etc. 
- It is basic to take note of that purchasers of Cloud services over Enterprises and the Digital Natives keep on requesting moderateness, which thusly is prompting the developments in the innovation supporting Cloud registering. For example, Edge Computing, Efficient Cooling Systems, Converged and Hyper-Converged Hardware Infrastructure are a portion of the advancements that are helping suppliers diminish the expense of administrations, making selection across the board.

- India keeps on outstanding a market that is flourishing under the double chance of serving household and worldwide interest just as getting a charge out of higher utilization of information with the approach of fast portable availability. With these elements in play, the chance to fabricate the Cloud showcase in India is noteworthy and promising.

- The Government has a critical task to carry out, as do different empowering influences. Explicit administrative headings will go about as the important impetus to the development of Cloud in India. Assurance of Data and Privacy is gradually turning into the backbone of the strategy creators' center, which we accept will empower confidence in the potential purchaser of Cloud administrations.

Key Drivers for growth of Cloud Computing based Startups in India

Below are some facts to support why cloud computing is becoming an attraction for tech-based startups in India:

\section{Information System and Technology is now available} for the sake of business purpose, we consumerized IT to get more benefits per usage.

Anytime - anywhere access: Increasing consumer requirements for anytime, anywhere access to products and services (device/platform agnostic, anytime and everywhere access). Cloud solutions are well suited to fulfill these requirements. No boundary to get access.

IoT Data eruption: Technological advances have led to emergence of multiple IoT-based

Solutions, large quantities of data will be generated by connected devices. Data generated by connected devices will be processed by Cloud applications.

Cloud Managed Service: Enterprises ' need to optimize ROI, reduce budgets, and cope with scarcity of Cloud experts drives spending on managed Cloud services(e.g. security as a service etc.)
Emphasis on Data Security and Privacy: Companies have to either build secured Cloud capabilities in-house or trust Cloud service providers or leverage best-in-class security and compliance tools from Cloud services providers.

\section{CONCLUSION}

In today's digital era one has to build their businesses on priority with a couple of the consumer trends and social problems that are prevailing in the society. Startups which are developing solutions for the masses of India will execute well. It's not about what technology one is developing, instead, it's more important what the opportunities are, or what experiences one is providing to the consumers. Sometimes startups may get packed into the idea that they only want to build a blockchain startup or an AI based startups or any technology based startups. However, it's not about developing the blockchain or AI technology, it's about how will one change consumers' lives, transform some of the business processes using those technologies. Today, with the digital and technological development of the country, there is sufficient connectivity resources. People have access to internet and mobile applications which gives them tremendous power. They can avail the latest tech and world-class tools right here in India to be able to grow their businesses. Eventually, it's about enthusiasm. You need to truly be in love with what you are doing. Our way of thinking must be that we should become hopelessly enamored with the issues not the solutions. Attempt to address the client's agony first as fast as you can. There's been an ocean of progress in the Indian startup environment and on the off chance that we consider it outwardly as a transformed channel, the mouth of the pipe presently has turned out to be wide, which has been incredibly useful for the business person. Along these lines, the victor in this is the business visionary or entrepreneurs. Furthermore, best of all, the financial specialists are stopping themselves in India these days since India is near five hundred billion dollar utilization showcase. Throughout the following seven to eight years, with $5-7 \%$ yearly development rate, we'll include around 500 billion dollars of new utilization. Conceivably that is the greatest chance to all the buyer organizations and organizations that rotate around the customer ventures.

\section{RCOMMENDATIONS}

$\checkmark$ Government should build monetary help for rising AI, Cloud and other front line innovative thoughts so more new startups rise in these zones.

$\checkmark$ Re-skill the work force to meet the technological needs.

$\checkmark$ Make these advanced technologies cost effective and secure for faster integration in businesses. 


\section{REFERENCES}

[1]. Arthur, W.B., 1989. Competing technologies, increasing returns, and lock in by historical events. Economic Journal 99 (1), 116-131.

[2]. Arthur, W.B., 1990. 'Silicon Valley' locational clusters: when do increasing returns imply monopoly? Mathematical Social Sciences 19 (3), 235-251.

[3]. Audretsch, D.B., 1998. Agglomeration and the location of innovative activity. Oxford Review of Economic Policy 14 (2), 18-29 (253-273).

[4]. Audretsch, D.B., Feldman, M.P., 1996. Innovative clusters and the industry life cycle. Review of Industrial Organization 11 (2), 253-273.

[5]. Chang, C. C. (2012). Exploring IT entrepreneurs' dynamic capabilities using Q-technique. Industrial Management \& Data Systems, 112(8), 1201-1216.

[6]. Cohen, W.M., Levinthal, D.A., 1990. Absorptive capacity: a new perspective on learning and innovation. Administrative Science Quarterly 35 (1), 128-152.

[7]. David, P., 1985. CLIO and the economics of QWERTY. American Economic Review 75, 332-337.

[8]. Ernst, D., 2001. The new mobility of knowledge: digital information systems and global flagship networks. Economics Study Area Working Papers.

[9]. Matzler, K., Friedrich von den Eichen, S., Anschober, M., \& Kohler, T. (2018). The crusade of digital disruption. Journal of Business Strategy, 39(6), 13-20

[10]. Scarmozzino, E., Corvello, V., \& Grimaldi, M. (2017). Entrepreneurial learning through online social networking in high-tech startups. International Journal of Entrepreneurial Behavior \& Research, 23(3), 406-425.

[11]. Sonderegger, P., \&Täube, F. (2010). Cluster life cycle and diaspora effects: Evidence from the Indian IT cluster in Bangalore. Journal of International Management, 16(4), 383-397.

[12]. Swiercz, P. M., \&Lydon, S. R. (2002). Entrepreneurial leadership in high-tech firms: a field study. Leadership \& Organization Development Journal, 23(7), 380-389.

[13]. Verkasalo, H. (2009). Analysis of mobile internet usage among early-adopters. info, 11(4), 68-82. 